\title{
PERBAIKAN PREDIKSI CUACA NUMERIK KEJADIAN CURAH HUJAN LEBAT TERKAIT DENGAN KEJADIAN LONGSOR DI BANJARNEGARA MENGGUNAKAN ASIMILASI DATA SATELIT
}

\author{
Improvement in Numerical Weather Prediction of Landslide-Associated \\ Heavy Rainfall Events over Banjarnegara Area by Using Assimilated \\ Satellite Data
}

\author{
Adi Mulsandi ${ }^{1)^{*}}$, Aries Kristianto ${ }^{1)}$ Achmad Zakir ${ }^{1)}$ \\ 1) Sekolah Tinggi Meteorologi Klimatologi dan Geofisika, Jalan Perhubungan I No. 5 \\ Kel. Pondok Betung, Kec. Pondok Aren, Tangerang Selatan, Banten. \\ *E-mail: adimulsandi@yahoo.com
}

\begin{abstract}
Intisari
Wilayah Banjarnegara terekspos dengan kejadian tanah longsor yang terjadi hampir setiap tahun. Hujan lebat merupakan salah satu faktor penting pemicu terjadinya longsor yang paling mungkin untuk diprediksi, sehingga prediksi hujan lebat yang akurat sangat dibutuhkan dalam sistem peringatan dini longsor. Namun demikian, keterbatasan peralatan pengamatan cuaca di Banjarnegara memberikan kendala tersendiri sehingga dibutuhkan teknik lain dalam pembuatan informasi prediksi cuaca di wilayah ini. Penelitian ini dibuat untuk memberikan kontribusi landasan ilmiah dalam membuat prakiraan cuaca menggunakan model Weather Research and Forecasting (WRF) dengan mengintegrasikan data pengamatan satelit menggunakan WRF Data Assimilation (WRF-DA) untuk memperbaiki kualitas data awal model. Hasil penelitian menunjukan bahwa prosedur asimilasi data satelit cuaca dapat memperbaiki data awal kandungan uap air di atmosfer $(+60 \%)$ beberapa jam sebelum kejadian hujan lebat. Sehingga hasil prediksi model cuaca numerik dengan menggunakan asimilasi data satelit (DA-SAT) menjadi lebih baik dibandingkan dengan yang tidak menggunakan asimilasi data (Non_DA). Hal ini ditunjukan dengan nilai bias model yang mengecil (-32\%) jika dibandingkan dengan data pengamatan penakar hujan stasiun. Hasil perbandingan data series waktu akumulasi curah hujan antara DA-SAT dan Non-DA memperlihatkan adanya perbedaan waktu tercapainya hujan maksimum dan juga perbedaan intensitasnya dimana skema Non-DA lebih lambat (+5 jam) dengan bias (-40\%) sementara DA-SAT lebih lambat 0.5 jam dengan bias (+8\%). Dapat disimpulkan bahwa asimilasi data satelit dapat memperbaiki kesalahan prediksi jumlah hujan dan waktu kejadiannya. Hasil penelitian ini dapat dijadikan rekomendasi penggunaan asimilasi data satelit dalam pembuatan informasi prediksi cuaca numerik di wilayah Banjarnegara.
\end{abstract}

Kata Kunci : WRF, WRF-DA, Asimilasi Data Satelit, Longsor Banjarnegara, Hujan Lebat.

\begin{abstract}
The Banjarnegara area is very much prone to landslides events that occur almost every year. Heavy rainfall is an important factor, which triggers predictable landslide events. Thus, accurate prediction of heavy rainfall will be much helpful in providing an early warning of landslide occurrence. Due to the limitation of available observation instruments in Banjarnegara, there is a need for an alternative measurement technique which can provide weather prediction information for this area. This research serve as a scientific basis in the development of a weather prediction model which uses Weather Research and Forecasting (WRF) model that integrates satellite observation data into the model via WRF-Data Assimilation (WRF-DA) mechanism to improve the initial data quality. The results shows that satellite data assimilation (DA-SAT) can improve the initial atmospheric moisture content data $(+60 \%)$ at several hours before a heavy rainfall event occurs. As such, results from DASAT-based numerical weather prediction model becomes much better compared to non-DA-SAT or non-assimilated data model. This is shown by the evident shrinking of model bias value (up to -32\%) when compared to individual station rain gauge observation. The resulting comparison between DA$S A T$ and non-DA-SAT rainfall accumulation time series data, shows the difference present in the amount of time required to reach maximum rainfall. In addition, there exist a rainfall intensity difference, where non-DA-SAT mechanism is slower (by +5 hours) with a bias of $-40 \%$, whereas $D A$ $S A T$ is slower by 0.5 hours with a bias of $+8 \%$. It can then be concluded that satellite data assimilation is able to reduce the errors present in rainfall amount prediction and its time of occurrence. The
\end{abstract}


results from this research can be used as a recommendations for using satellite data assimilation in the development of a numerical weather prediction information system in the Banjarnegara area.

\section{Keywords : WRF, WRF-DA, Satellite Data Assimilation, Banjarnegara Landslide, Heavy Rainfall.}

\section{PENDAHULUAN}

Hamilton (1973) menjelaskan bahwa wilayah kepulauan Indonesia secara geografis terletak pada pertemuan empat lempeng tektonik, yakni lempeng Benua Asia, Benua Australia, lempeng Samudra Hindia dan Samudra Pasifik. Sementara itu, pada bagian selatan dan timur wilayah Indonesia terdapat sabuk vulkanik (volcanic arc) yang memanjang dari pulau Sumatera-Jawa-Nusa Tenggara dan Sulawesi. Kedua kondisi tersebut menjadikan wilayah Indonesia sering dilanda gempa bumi baik yang dipicu oleh aktivitas vulkanik maupun tektonik. Selain itu, kondisi tersebut juga menyebabkan wilayah Indonesia rentan terhadap terjadinya pergerakan tanah yang masif atau yang disebut dengan longsor. Kerentanan tersebut menjadi lebih meningkat dengan besarnya curah hujan yang diterima oleh wilayah Indonesia pada setiap tahunnya, sebagai konsekuensi letak geografis di wilayah ekuator.

Tanah longsor adalah suatu produk dari proses gangguan keseimbangan yang menyebabkan bergeraknya massa tanah dan batuan dari tempat yang lebih tinggi ke tempat yang lebih rendah (Mubekti \& Alhasanah, 2008). Pada prinsipnya kejadian tanah longsor dapat terjadi karena dipicu oleh gaya pendorong pada lereng yang memiliki massa lebih besar dari pada gaya penahan. Gaya pendorong ini dipengaruhi oleh besarnya sudut lereng, kandungan air, beban dan berat jenis tanah batuan. Sedangkan gaya penahan dipengaruhi oleh kekuatan batuan dan kepadatan tanah. Air yang merupakan salah satu gaya pendorong pada kejadian longsor dapat dipicu oleh peningkatan intensitas curah hujan. Dalam beberapa model longsor, faktor gaya pendorong air yang dihasilkan dari curah hujan memiliki nilai bobot yang tinggi. Hal ini mengindikasikan betapa krusialnya peran curah hujan dalam kejadian longsor. Beberapa kajian telah dilakukan untuk menjelaskan hubungan antara curah hujan dan kejadian longsor (Keefer et al. 1987; Chan et al. 2003; Glade et al. 2000; Crosta \& Frattini, 2001; Guzzetti et al. 2008; Baum \& Godt, 2010; Huggel et al. 2010; Martelloni et al. 2012; Rosi et al. 2016). Oleh karena itu penyediaan informasi prediksi curah hujan menjadi sangat penting karena hampir setiap model longsor membutuhkan inputan curah hujan sebagai faktor pemicunya. Hal ini yang menjadi motivasi kajian ini dilakukan yaitu untuk menyediakan informasi prediksi hujan lebat pemicu longsor pada skala lokal dimana informasi ini sulit dipenuhi oleh Badan Meteorologi Klimatologi dan Geofisika (BMKG) karena keterbatasan sumber daya manusia dan infrastruktur.

Keterbatasan jumlah titik pengamatan stasiun dan kemampuan komputasi yang dimiliki oleh BMKG menjadi kendala utama untuk dapat menyediakan informasi prakiraan cuaca pada skala lokal. Hasil verifikasi akurasi prediksi cuaca operasional BMKG memperlihatkan skor yang sangat rendah dalam memprediksi hujat lebat (Gustari, 2012). Oleh karena itu kerjasama serta dukungan pemerintah daerah perlu digalakan untuk menggagas kemandirian teknologi tanggap bencana di tingkat lokal. Kajian ini menjadi bagian kecil dari kegiatan penelitian sistem peringatan dini bencana longsor sebagai upaya mitigasi di wilayah rawan longsor Banjarnegara.

Untuk menyediakan informasi prediksi hujan lebat sebagai pemicu longsor dalam kajian ini digunakan model prakiraan cuaca numerik WRF. Model ini sangat menjanjikan karena disamping mudah dalam mengoperasikanya juga tidak membutuhkan infrastruktur yang mahal.

Tahapan penting yang perlu dilakukan sebelum model ini digunakan secara operasional adalah pengujian skill model dalam mensimulasikan kejadian hujan lebat. Oleh karena model WRF menyediakan begitu banyak skema parameterisasi yang memiliki kelebihan dan kelemahan masing-masing, maka pengujian sensifitas skema parameterisasi yang tersedia perlu untuk dilakukan. Untuk studi kasus kejadian longsor ini telah dijalankan 30 skema konfigurasi model untuk selanjutnya dipilih yang terbaik dalam memprediksi kejadian curah hujan lebat yang memicu kejadian longsor di desa Sidengok Banjarnegara pada tanggal 24 September 2016. Tahapan selanjutnya adalah perbaikan model prediksi cuaca numerik melalui prosedur asimilasi data untuk memperbaiki kualitas data inisial model. Penelitian ini dibuat untuk melakukan tahapan kedua perbaikan kualitas prediksi cuaca numerik yaitu dengan melakukan asimilasi data satelit.

\section{METODE}

Penelitian ini menggunakan beberapa data yang terdiri dari data model reanalisis untuk menganalisis kondisi atmosfer pada saat kejadian, data model prediksi untuk kondisi awal dan kondisi batas model, data satelit untuk diasimilasikan pada model, serta data pengamatan penakar hujan untuk verifikasi hasil keluaran model.

Data pengamatan penakar hujan diperoleh dari stasiun pengamatan geofisika Banjarnegara pada tanggal 20 Juni dan 23 September 2016. Sementara itu data model reanalisis yang digunakan adalah data Final Analysis (FNL) yang diperoleh dari 
website yaitu https://rda.ucar.edu. Data FNL memiliki resolusi $1 \times 1$ derajat yang diperbaharui setiap enam jam. Data ini diproduksi oleh National Center for Environmental Prediction (NCEP) Global Data Assimilation System (GDAS) yang secara kontinu mengumpulkan data melaui Global Telecommunication System (GTS) dan sumber data lain untuk dianalisis. Analisis tersedia untuk permukaan, 26 level dari 1000-10 milibar pada lapisan batas atmosfer, dan beberapa lapisan sigma, tropopause, dan lapisan lainnya (Kalnay et al, 1996). Dalam penelitian ini data FNL digunakan untuk menganalisis kondisi atmosfer pada saat kejadian hujan lebat yang memicu kejadian longsor di Banjarnegara untuk dua studi kasus.

Data yang digunakan untuk simulasi prediksi pada model WRF adalah data Global Forecast System (GFS), yaitu model prediksi cuaca yang diproduksi oleh NCEP. Data ini memiliki cakupan global dengan resolusi hingga $28 \mathrm{~km}$, yang digunakan untuk operasional prediksi cuaca hingga 16 hari ke depan. Parameter yang digunakan untuk prediksi menggunakan model yaitu temperatur, komponen angin arah zonal dan meridional, kelembapan, ketinggian geopotensial, dan tekanan permukaan. Data GFS dapat diperoleh dari NCEP GDAS. Dalam penelitian ini data digunakan data GFS dengan resolusi $0.250 \times 0.250$ sampai dengan 36 jam dengan 12 jam pertama pada hari sebelumnya digunakan sebagai waktu spin up model (Kanamitsu, 1989; Kanamitsu et al, 1991; Iredell et al, 2002). Data GFS dapat diunduh dari situs https://rda.ucar.edu/datasets/ ds084.1/.

Karena wilayah Banjarnegara hanya terdapat satu titik stasiun pengamatan yang memiliki data pengamatan curah hujan tiap satu jam maka untuk melakukan verifikasi hasil simulasi model secara spasial digunakan data estimasi hujan dari Global Satellite Mapping of Precipitation (GSMaP). GSMaP adalah data curah hujan global beresolusi tinggi ( 5 $\mathrm{km} \times 5 \mathrm{~km}$ ) tersedia setiap jam dan memiliki presisi tinggi yang diestimasi dari data satelit dengan menggunakan kombinasi sensor microwave (MW) dan infrared (IR) dengan menggabungkan beberapa algoritma yaitu Global Precipitation Measurement (GPM-Core) Microwave Imager (GMI), Tropical Rainfall Measuring Mission (TRMM) Microwave Imager (TMI), Global Change Observation Mission second Advance Microwave Scanning Radiometer (GCOM-W AMSR2), Defense Meteorological Satellite Program (DMSP) Series Special Sensor Microwave Imager Sounder (SSMIS), National Oceanic and Atmospheric Administration (NOAA) Series Advanced Microwave Sounding Unit (AMSU), Meteorological Operational satellite programme (METOP) Series AMSU, dan data geostasioner IR (Kubota et al, 2007). GSMaP diproduksi oleh Japan Aerospace Exploration Agency (JAXA) Precipitation Measuring Mission (PMM). Data ini dapat diperoleh dari situs $\mathrm{ftp} / / /$ hokusai.eorc.jaxa.jp/realtime/.

Data satelit yang digunakan yaitu satelit NOAA dengan menggunakan sensor AMSU-A dan
Microwave Humidity Sounder (MHS) dalam format bufr, yang diperoleh dari situs https://rda.ucar.edu/datasets/ds735.0/. Data satelit yang digunakan pertama adalah AMSU-A yang memiliki 15 kanal cross track, stepped line scanning (garis), radiometer dengan daya microwave. Kanal 4-14 digunakan dalam asimilasi untuk mendeteksi parameter $\mathrm{T}$ (temperatur) pada 11 lapisan (permukaan - $45 \mathrm{~km}$ ). AMSU-A didesain untuk mengukur profil temperatur atmosfer global dengan menggunakan pita absorpsi oksigen untuk mengukur temperatur tiap lapisan atmosfer, dan kanal jendela atmosfer 23.8, 31.4, dan $89 \mathrm{GHz}$ untuk mengukur temperatur dan emisivitas permukaan (Goodrum, 2009). AMSU-A merupakan bagian dari Advanced TIROS Operational Vertical Sounder (ATOVS).

Sementara itu untuk sensor MHS (Microwave Humidity Sounder) yang beroperasi pada frekuensi 89-190 GHz, memiliki 5 kanal microwave, dan radiometer daya penuh. Kanal 2-5 diasimilasi untuk mendeteksi parameter $\mathrm{Q}$ (kelembapan) pada 2 lapisan (permukaan - $400 \mathrm{hPa}$ ). MHS didesain untuk memperoleh data atmospheric ice, tutupan awan, dan hujan. Kanal H1 (89 GHz) dan H2 (157 $\mathrm{GHz}$ ) MHS merupakan jendela atmosfer yang mendeteksi uap air pada lapisan bawah atmosfer dan dekat permukaan (Bonsignori, 2007). MHS adalah penerus dari sensor AMSU- B yang juga bagian dari ATOVS.

Semua data satelit di atas dapat diperoleh dari NCEP GDAS Satellite Data yang dapat diakses di alamat https://rda.ucar.edu/datasets/ds735.0/. Data tersebut tersedia dalam format bufr dengan resolusi spasial $1^{0} \times 1^{0}$ tersedia setiap 6 jam yang dapat langsung digunakan sebagai data asimilasi pada model WRFDA.

Penelitian ini mengkaji dua studi kasus kejadian longsor Banjarnegara yang terjadi yaitu pada tanggal 20 Juni dan 23 September 2016. Prosedur pengolahan data yang digunakan untuk setiap kasus dalam penelitian ini adalah sebagai berikut:

\subsection{Analisis Kondisi Atmosfer}

Untuk mempelajari kondisi atmosfer terkait dengan kejadian hujan lebat di Banjarnegara, maka dilakukan analisis dinamis dan fisis atmosfer. Untuk mengetahui dinamika atmosfer pada saat kejadian hujan lebat digunakan parameter angin dari data reanalisis FNL. Sedangkan, analisis fisis atmosfer dilihat data suhu kecerahan satelit cuaca himawari untuk mengetahui pola konveksi pada saat kejadian.

\subsection{Simulasi Prediksi Cuaca Numerik}

Untuk melakukan simulasi prediksi cuaca satu hari sebelum kejadian hujan lebat digunakan model Weather Research and Forecast (WRF) yaitu program komputer yang dibangun dari persamaan matematis untuk menggambarkan pergerakan fluida (Skamarock et al, 2008). 
Tabel 1. Konfigurasi Model WRF.

\begin{tabular}{llll}
\hline Konfigurasi & Domain 1 & Domain 2 & Domain 3 \\
\hline Resolusi grid horizontal & $27 \mathrm{~km}$ & $9 \mathrm{~km}$ & $3 \mathrm{~km}$ \\
\hline Resolusi temporal & 180 menit & 180 menit & 180 menit \\
\hline Skema mikrofisis & WSM3 & WSM3 & WSM3 \\
\hline $\begin{array}{l}\text { Skema parameterisasi } \\
\text { cumulus }\end{array}$ & Kain-Fritsch (KF) & Kain-Fritsch (KF) & Kain-Fritsch (KF) \\
\hline Skema PBL & $\begin{array}{l}\text { Yonsei University } \\
\text { Scheme (YSU) }\end{array}$ & $\begin{array}{l}\text { Yonsei University } \\
\text { Scheme (YSU) }\end{array}$ & $\begin{array}{l}\text { Yonsei University } \\
\text { Scheme (YSU) }\end{array}$ \\
\hline $\begin{array}{l}\text { Skema radiasi } \\
\text { gelombang pendek }\end{array}$ & Dudhia Scheme & Dudhia Scheme & Dudhia Scheme \\
\hline $\begin{array}{l}\text { Skema radiasi } \\
\text { gelombang panjang }\end{array}$ & $\begin{array}{l}\text { Rapid Radiative } \\
\text { Transfer Model } \\
\text { (RRTM) }\end{array}$ & $\begin{array}{l}\text { Rapid Radiative } \\
\text { Transfer Model } \\
\text { (RRTM) }\end{array}$ & $\begin{array}{l}\text { Rapid Radiative } \\
\text { Transfer Model } \\
\text { (RRTM) }\end{array}$ \\
\hline Jumlah level vertikal & 32 lapisan & 32 lapisan & 32 lapisan \\
\hline
\end{tabular}

Tabel 2. Perbandingan hasil pengujian sensitivitas skema mikrofisika dan konveksi pada satu kasus hujan sangat lebat di Banjarnegara.

\begin{tabular}{cccccccc}
\hline Skema & Mikrofisik & Konveksi & Korelasi & Skema & Mikrofisik & Konveksi & Korelasi \\
\hline $\mathbf{1}$ & Kessler & KF (0) & 0 & $\mathbf{1 6}$ & WSM3 & BMJ & 0.36 \\
\hline $\mathbf{2}$ & Kessler & KF & 0 & $\mathbf{1 7}$ & WSM3 & Grell 3d $(0)$ & -0.10 \\
$\mathbf{3}$ & Kessler & BMJ (0) & 0 & $\mathbf{1 8}$ & WSM3 & Grell 3d & 0.74 \\
\hline $\mathbf{4}$ & Kessler & BMJ & 0 & $\mathbf{1 9}$ & Eta & KF $(0)$ & 0.15 \\
\hline $\mathbf{5}$ & Kessler & Grell 3d (0) & 0.15 & $\mathbf{2 0}$ & Eta & KF & 0.77 \\
$\mathbf{6}$ & Kessler & Grell 3d & 0.16 & $\mathbf{2 1}$ & Eta & BMJ $(0)$ & 0.01 \\
\hline $\mathbf{7}$ & Lin & KF (0) & 0.14 & $\mathbf{2 2}$ & Eta & BMJ & 0.13 \\
\hline $\mathbf{8}$ & Lin & KF & 0.10 & $\mathbf{2 3}$ & Eta & Grell 3d $(0)$ & 0.26 \\
\hline $\mathbf{9}$ & Lin & BMJ (0) & 0.43 & $\mathbf{2 4}$ & Eta & Grell 3d & 0.21 \\
\hline $\mathbf{1 0}$ & Lin & BMJ & 0.05 & $\mathbf{2 5}$ & WSM6 & KF $(0)$ & -0.09 \\
\hline $\mathbf{1 1}$ & Lin & Grell 3d (0) & -0.05 & $\mathbf{2 6}$ & WSM6 & KF & -0.03 \\
\hline $\mathbf{1 2}$ & Lin & Grell 3d & -0.12 & $\mathbf{2 7}$ & WSM6 & BMJ $(0)$ & -0.13 \\
\hline $\mathbf{1 3}$ & WSM3 & KF $(0)$ & -0.06 & $\mathbf{2 8}$ & WSM6 & BMJ & 0.63 \\
\hline $\mathbf{1 4}$ & WSM3 & KF & 0.90 & $\mathbf{2 9}$ & WSM6 & Grell 3d $(0)$ & 0.10 \\
\hline $\mathbf{1 5}$ & WSM3 & BMJ $(0)$ & 0.09 & $\mathbf{3 0}$ & WSM6 & Grell 3d & 0.02 \\
\hline
\end{tabular}

Model WRF merupakan sistem prediksi cuaca numerik skala meso generasi baru yang didesain untuk keperluan penelitian atmosfer dan operasional prediksi cuaca. Penelitian ini menggunakan model WRF dan asimilasi data 3DVar. Untuk selanjutnya masing-masing eksperimen akan diberi nama NonDA untuk simulasi tanpa asimilasi data dan DA-SAT untuk simulasi dengan menggunakan data asimilasi. Pengaturan model secara lengkap dapat dilihat pada Tabel 1.

Model WRF memiliki banyak opsi parameterisasi, beberapa diantaranya dirancang khusus untuk data real dan resolusi tinggi. Diperlukan tahapan pemilihan konfigurasi skema untuk mengetahui kombinasi parameterisasi yang paling baik dalam memprediksi cuaca di Jakarta sehingga dibutuhkan pengujian yang cukup sebelum digunakan untuk prediksi.

Pengujian skema mikrofisika dan parameterisasi konveksi pada model WRF tersebut dilakukan terhadap satu kejadian hujan sangat lebat di Banjarnegara yang terjadi pada 24 September 2016. Tanggal ini dipilih dengan pertimbangan berdasarkan ketersediaan data. Hasil yang ditampilkan pada Tabel 2 merupakan nilai korelasi antara curah hujan pengamatan stasiun geofisika Banjarnegara dan curah hujan pada satu titik terdekat hasil keluaran WRF di tempat yang sama.

Berdasarkan nilai keandalan yang ditunjukan di Tabel 1 diperoleh kombinasi skema konveksi dan mikrofisika yang memberikan hasil yang lebih baik yaitu KF dan WSM3.

\subsection{Menjalankan Model WRFDA}

WRFDA adalah program WRF yang menyediakan fasilitas asimilasi data. Jenis data yang dapat diasimilasikan adalah data radar, satelit, observasi udara atas, dan observasi udara permukaan. Output dari WRFDA akan digunakan sebagai data inisiasi dalam model WRF-ARW. 
Tujuan utama sistem asimilasi WRFDA adalah mengestimasi secara optimal kondisi aktual atmosfer pada waktu analisis melalui solusi persamaan iteratif yang telah ditetapkan (cost function) (Ide et al, 1997), yaitu sebagai berikut:

$$
\begin{aligned}
J(x)=J_{b}(x)+J_{o} & (x) \\
& =\frac{1}{2}\left(x-x^{b}\right)^{T} \boldsymbol{B}^{-1}\left(x-x^{b}\right) \\
& +\frac{1}{2}\left(y-y^{o}\right)^{T}(\boldsymbol{E}+\boldsymbol{F})^{-1}(y \\
& \left.-y^{o}\right)(2.1)
\end{aligned}
$$

Dengan:

$$
\begin{aligned}
& \mathrm{Jb}=\text { cost function tebakan pertama (background) } \\
& \text { dan observasi } \\
& \mathrm{Jo}=\text { cost function tebakan pertama (background) } \\
& \text { dan observasi } \\
& \mathrm{X} \text { = masing-masing adalah data analisis yang } \\
& \text { diharapkan } \\
& \mathrm{xb}=\text { data tebakan pertama (background). } \\
& y=\text { data observasi } \\
& \text { yo = data observasi dalam grid model } \\
& \mathrm{B}=\text { background error (BE) } \\
& \mathrm{E}=\text { error observasi, dan } \\
& \mathrm{F}=\text { error representatif }
\end{aligned}
$$

Error representatif berasal dari ketidakakuratan operator observasi dalam mentransformasi analisis grid $\mathrm{x}$ ke ruang observasi y.

Pada tahapan ini data radiance satelit diolah menggunakan aplikasi WRFDA untuk memperbaiki data kondisi awal model. Data radiance satelit AMSU-A dan MHS digunakan untuk memodifikasi data inisial model yang sebelumnya menggunakan data GFS. Perpaduan antara model GFS dan pengamatan satelit akan menghasilkan estimasi kondisi atmosfer pada awal waktu menjadi lebih akurat.

\subsection{Verifikasi}

Langkah terakhir dari penelitian ini adalah verifikasi untuk mengetahui keandalan hasil keluaran model Non-DA dan DA-SAT dibandingkan dengan data curah hujan hasil pengamatan stasiun Geofisika Banjarnegara dan data curah hujan GSMAP untuk verifikasi spasial. Untuk mengetahui pengaruh asimilasi, data satelit ditampilkan data kondisi awal parameter kelembapan yang dapat merepresentasikan kandungan uap air di atmosfer sebelum dan sesudah dilakukan asimilasi.

\section{HASIL DAN PEMBAHASAN}

Analisis data curah hujan untuk menentukan intensitas kejadian hujan sangat lebat berdasarkan kriteria operasional yang digunakan oleh BMKG (Badan Meteorologi Klimatologi dan Geofisika).
Dalam kriteria tersebut disebutkan bahwa nilai intensitas untuk kejadian hujan lebat adalah 20 $\mathrm{mm} / \mathrm{jam}$ atau $100 \mathrm{~mm} / \mathrm{hari}$.

\subsection{Kasus Kejadian Longsor Tanggal 25 September 2016}

\subsubsection{Analisis Kondisi Atmosfer}

Untuk menguji kehandalan model WRF dalam memprediksi kejadian hujan lebat pada satu hari sebelum terjadi longsor digunakan studi kasus pertama yaitu tanggal 24 September 2016. Menurut laporan BPPD, longsor di desa Sidengok Banjarnegara terjadi pada tanggal 25 September 2016 pukul 07.00 WIB. Longsor menimbun beberapa rumah dan dilaporkan menimbulkan satu korban jiwa. Berdasarkan laporan BNPB di lapangan kejadian longsor sendiri dipicu oleh hujan lebat dari mulai pukul 12.00 WIB hingga malam hari satu hari sebelum kejadian longsor yaitu tanggal 24 September 2016. Namun demikian menurut pengamatan stasiun geofisika Banjarnegara, yang berjarak $27 \mathrm{~km}$ dari lokasi longsor, hujan tercatat dimulai pukul 15.00 hingga 17.00 dengan puncak hujan terjadi pada pukul 16.00 WIB yaitu sebesar 44 mm/jam (Gambar 1).

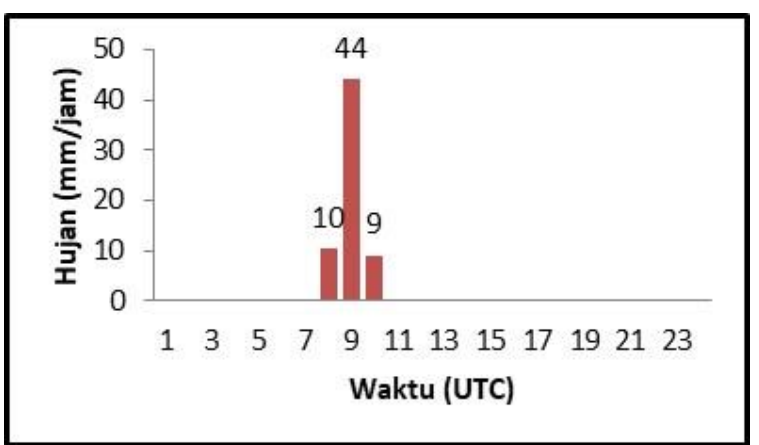

Gambar 1. Curah hujan terukur di stasiun Geofisika Banjarnegara tanggal 24 September 2016.

Kejadian hujan lebat yang memicu longsor di desa Sidengok berlangsung dalam periode transisi dari musim kemarau ke musim hujan. Analisis dinamika atmosfer (Gambar 2) memperlihatkan bahwa angin timuran belum sepenuhnya berakhir. Sementara itu angin baratan sudah mulai aktif. Kondisi ini menghasilkan dua pertemuan masa udara di sekitar wilayah jawa tengah yang memicu pertumbuhan awan konvektif di wilayah jawa tengah bagian selatan. Dari pengamatan citra satelit (Gambar 3) memperlihatkan adanya konsentrasi awan konvektif di sekitar wilayah Banjarnegara dan sekitarnya.

Di lokasi kejadian awan konvektif terlihat mulai tumbuh secara intensif dimulai pada pukul $12.00 \mathrm{WIB}$ hingga pukul 17.00 WIB (Gambar 3). Sistem awan konvektif ini ditengarai yang menyebabkan terjadinya hujan lebat di lokasi kejadian longsor. 

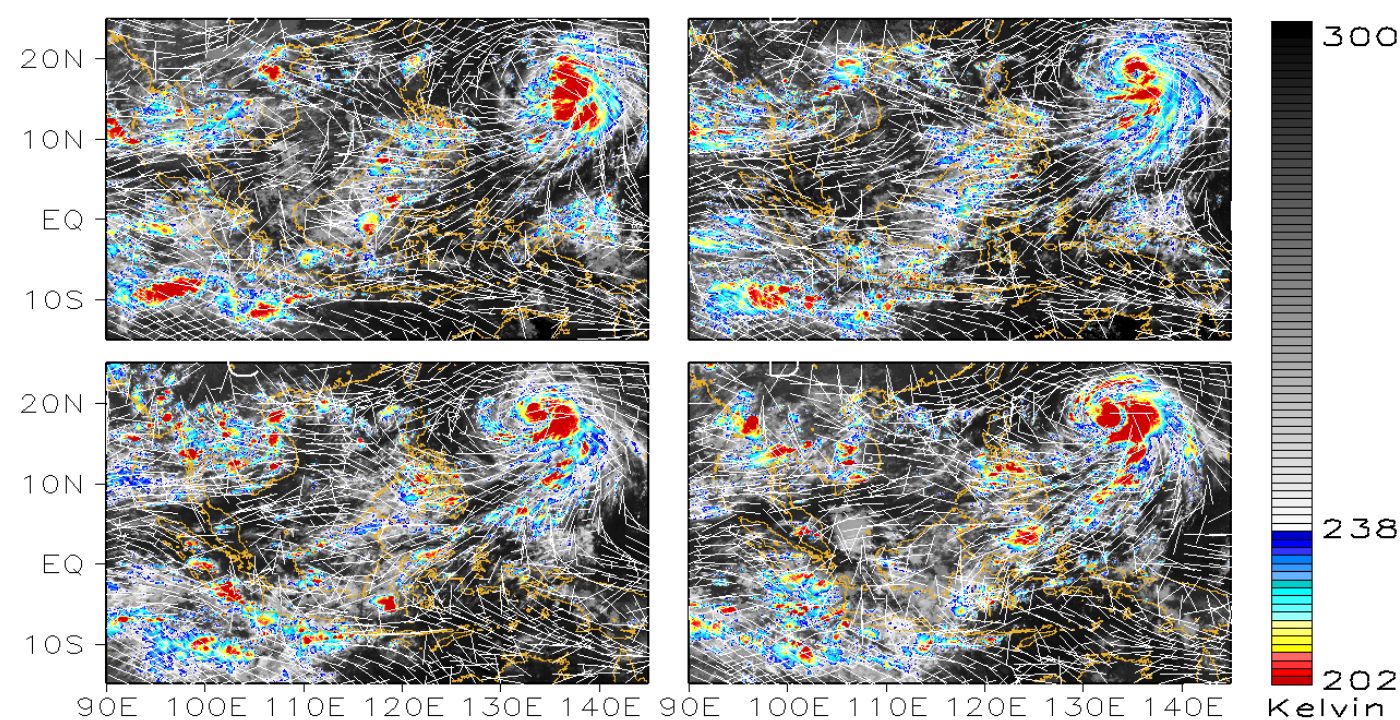

Gambar 2. Overlay angin dan awan untuk menggambarkan kondisi dinamika atmosfer saat kejadian hujan lebat yang mengakibatkan longsor di Banjarnegara tanggal 24 September 2016. Panel kiri atas, kanan atas, kiri bawah dan kanan bawah masing-masing untuk pukul 00, 06,12 dan 18 UTC.

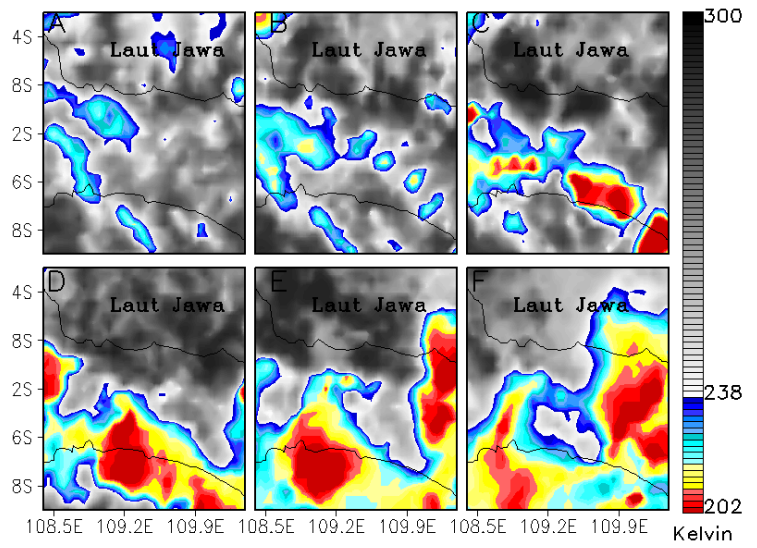

Gambar 3. Sebaran awan konvektif saat kejadian hujan lebat yang mengakibatkan longsor di Banjarnegara tanggal 24 September 2016. Gambar A, B, C, D, E, dan F masing-masing adalah untuk pukul 07, 08, 09, 10, 11, dan 12 UTC.

Jika dianalisis luasan sistem awan pada saat kejadian mencapai $100.000 \mathrm{~km}^{2}$. Secara luasan sistem ini memenuhi kriteria sebagai meso scale convective complex (MCC). Namun demikian perlu dianalisis lebih lanjut dengan kriteria MCC lainnya. Gambar 4 menunjukan irisan sistem awan secara zonal dan meridional untuk melihat besarnya sistem awan yang terbentuk saat kejadian hujan lebat. Dapat dilihat bahwa sistem awan pada saat itu memiliki panjang secara horizontal arah zonal sekitar $400 \mathrm{~km}$ dan arah meridional sekitar $300 \mathrm{~km}$.

Pantauan kejadian hujan secara spasial disajikan dengan menggunakan data estimasi hujan berbasis satelit yaitu data GSMAP (Gambar 5). Pada Gambar 5 terlihat bahwa data GSMAP tidak menangkap kejadian hujan lebat di lokasi kejadian longsor pada jam 09.00 UTC seperti yang tecatat di data pengamatan stasiun. Namun demikian pada jam 11 dan 12 UTC hujan dengan intensitas sedang terpantau di wilayah kejadian longsor.

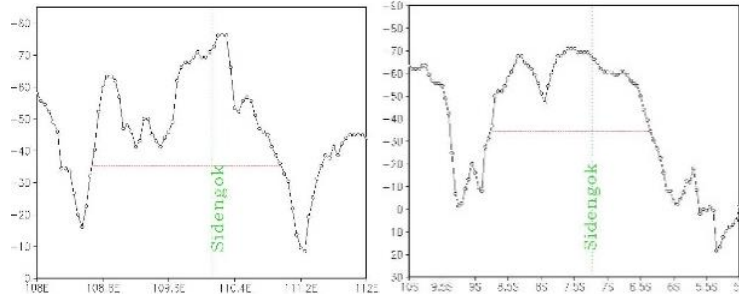

Gambar 4. Irisan zonal (kiri) dan meridional (kanan) dari penampang sistem awan di lokasi kejadian.

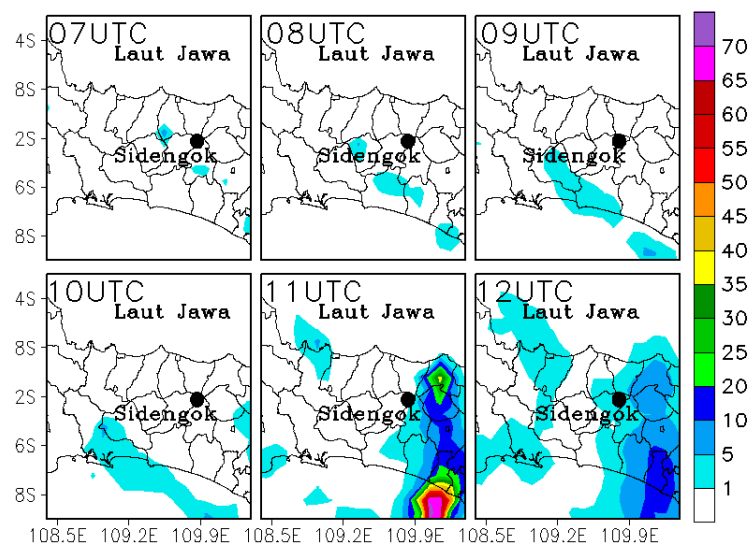

Gambar 5. Distribusi hujan spasial data GSMAP tanggal 24 September 2016.

\subsubsection{Keandalan Model WRF dalam Mensimulasikan Kejadian Hujan Lebat Pemicu Longsor}

Untuk selanjutnya melakukan analisis hasil simulasi kejadian hujan lebat menggunakan model WRF. Hasil simulasi kejadian hujan lebat dengan menggunakan eksperimen Non-DA memperlihatkan bahwa eksperimen tersebut gagal menangkap kejadian hujan lebat yang menyebabkan longsor. Sebaliknya pada eksperimen DA-SAT terlihat kejadian hujan lebat tersimulasikan dengan baik di wilayah kejadian longsor (Gambar 6). Hasil ini 
mengindikasikan bahwa prosedur asimilasi data satelit dapat memperbaiki hasil simulasi. Perbaikan ini terjadi karena prosedur asimilasi dapat memperbaiki ketersediaan uap air hal ini dapat terlihat dari perbedaan parameter $\mathrm{RH}$ yang merepresentasikan kandungan uap air di atmosfer.

Pada Gambar 7 memperlihatkan perbandingan nilai parameter $\mathrm{RH}$ pada data inisial model untuk eksperimen Non-DA dan eksperimen DA-SAT. Terlihat bahwa nilai parameter $\mathrm{RH}$ pada eksperimen DA-SAT memiliki nilai yang lebih tinggi (60\%) dibandingan nilai parameter $\mathrm{RH}$ di eksperimen Non-DA. Hal ini mengindikasikan bahwa prosedur asimilasi data dapat memodifikasi nilai parameter $\mathrm{RH}$ pada data inisial kondisi model karena pada tanggal kejadian terjadi hujan lebat sehingga ketersediaan uap air di atmosfer tinggi diindikasikan dengan nilai $\mathrm{RH}$ yang tinggi.

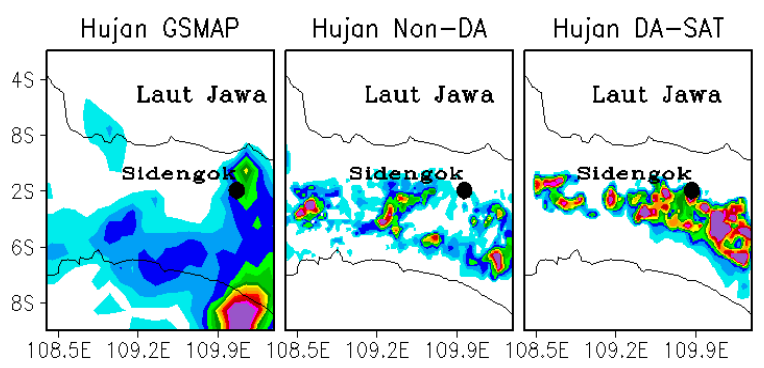

$5 \quad 1015202530354045505560 \quad 6570 \mathrm{~mm}$

Gambar 6. Perbandingan distribusi spasial hujan akumulasi 3 jam (8, 9 dan 10 UTC) antara data GSMAP, hujan Non-DA dan DA-SAT tanggal 24 September 2016.
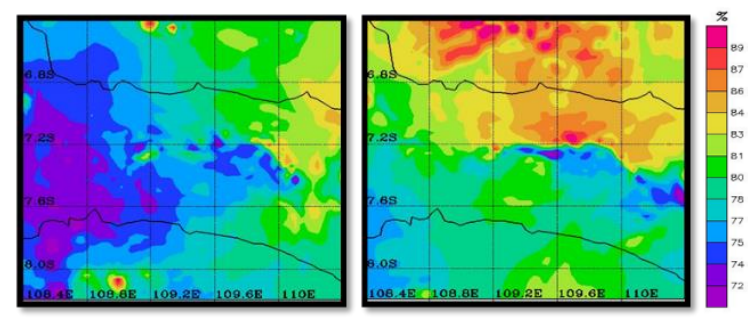

Gambar 7. Parameter kelembapan WRF non-DA (kiri) dan parameter kelembapan WRF-DA Satelit.

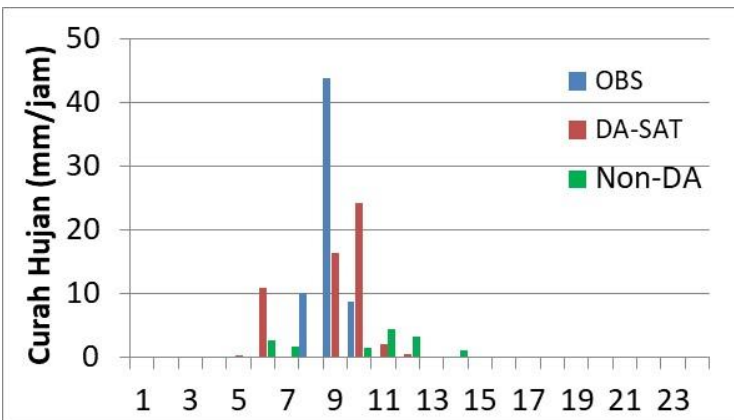

Gambar 8. Perbandingan hujan antara hasil simulasi kejadian hujan eksperimen Non-DA dan DA-SAT dengan data pengamatan permukaan di stasiun Geofisika Banjarnegara tanggal 24 September 2016.
Perbandingan nilai curah hujan antara hasil simulasi eksperimen Non-DA, DA-SAT dan data pengamatan curah hujan stasiun Geofisika Banjarnegara memperlihatkan dengan jelas bahwa prosedur asimilasi dapat memperkecil bias model dari 40\% menjadi 8\% (Gambar 8). Terlihat bahwa nilai hujan yang dihasilkan oleh eksperimen Non-DA jauh lebih underestimate dibandingkan dengan nilai curah hujan hasil simulasi eksperimen DA-SAT.

Hasil perbandingan data series waktu akumulasi curah hujan antara data observasi (maksimum jam 8.30 UTC) model dengan asimilasi data (maksimum jam 8.30 UTC) dan tanpa asimilasi (maksimum jam 13 UTC) memperlihatkan adanya perbedaan waktu mulai terjadinya hujan dimana eksperimen Non-DA lebih lambat sekitar 5 jam (Gambar 9). Keterlambatan ini diduga karena simulasi dalam penelitian ini menggunakan skema cold start. Meskipun sudah diatasi dengan spin up 12 jam namun ternyata masih menghasilkan lag time dalam produksi hujan di dalam simulasi.

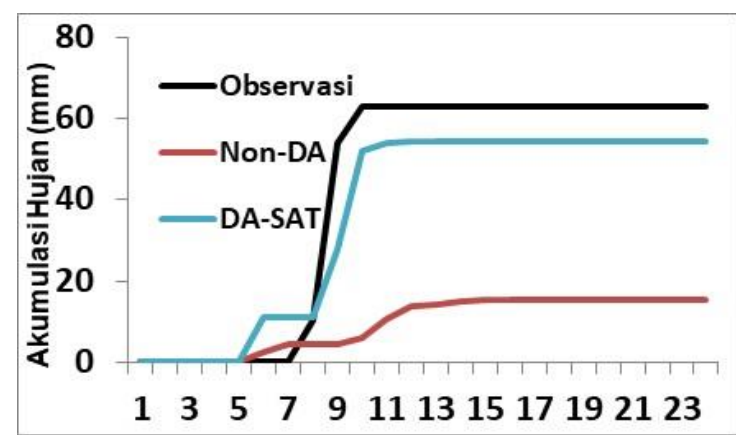

Gambar 9. Perbandingan akumulasi curah hujan antara hasil simulasi eksperimen Non-DA dan DA-SAT dengan data pengamatan di stasiun Geofisika Banjarnegara tanggal 24 September 2016.

\subsection{Kasus Kejadian Longsor Tanggal 18 Juni 2016}

\subsubsection{Analisis Kondisi Atmosfer}

Hasil laporan BPPD, longsor di desa Gumelem yang menyebabkan 7 orang meninggal terjadi pada malam hari tanggal 18 Juni 2018. Kronologisnya, terjadi hujan deras sejak pukul 14.30 WIB. Sayangnya kejadian hujan lebat tersebut tidak tercatat oleh stasiun Geofisika Banjarnegara sehingga sulit dilakukan analisis.

Analisis dinamika atmosfer (Gambar 10) memperlihatkan bahwa angin timuran sedang berlangsung. Pada saat bersamaan terdapat pusat tekanan rendah di sekitar wilayah Kalimantan yang menyebabkan angin timuran dari benua Australia berbelok di sekitar wilayah Jawa tengah. Kondisi ini menghasilkan dua pertemuan masa udara di sekitar wilayah ini yang memicu pertumbuhan awan konvektif di wilayah bagian selatan. Dari pengamatan citra satelit (Gambar 11) terlihat adanya konsentrasi awan konvektif di sekitar wilayah Banjarnegara dan sekitarnya. 

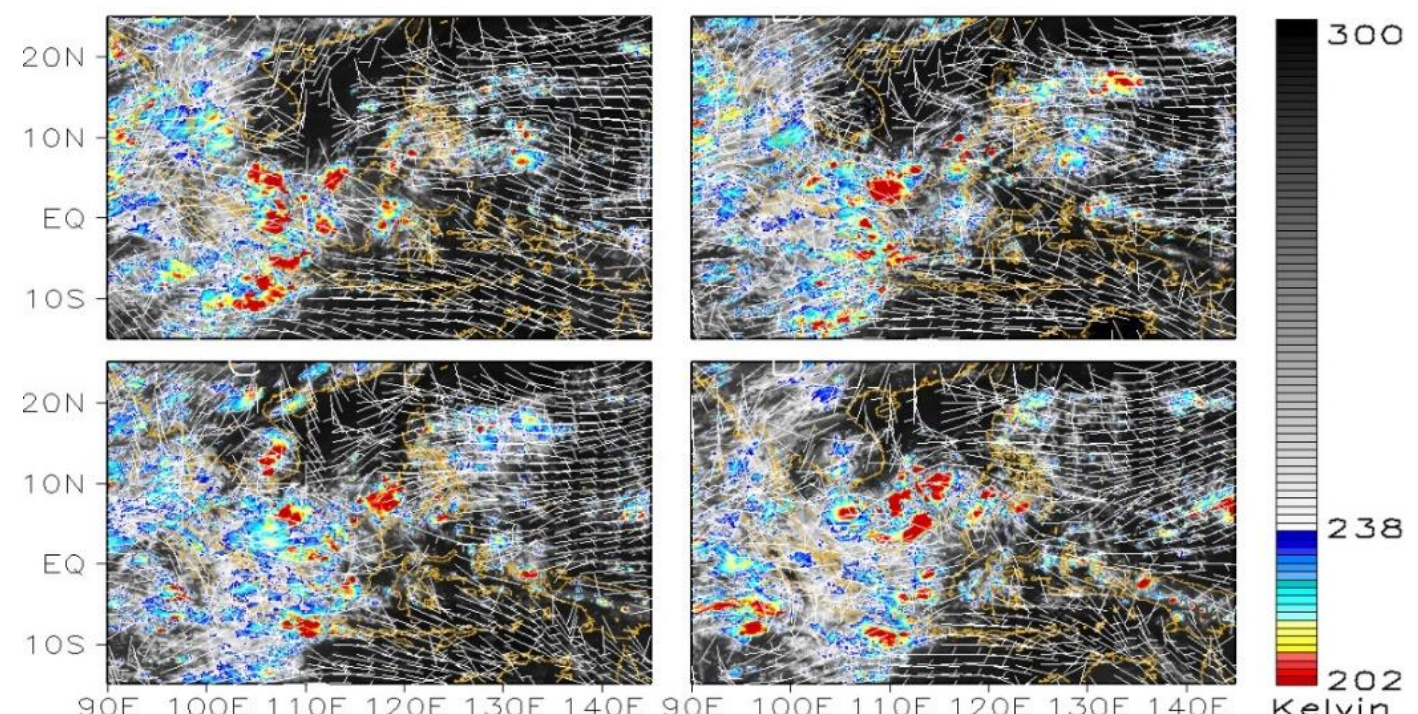

Gambar 10. Sama seperti gambar 2 tapi untuk kasus tanggal 16 Juni 2016. Panel kiri atas, kanan atas, kiri bawah dan kanan bawah masing-masing untuk pukul 00, 06,12 dan 18 UTC.

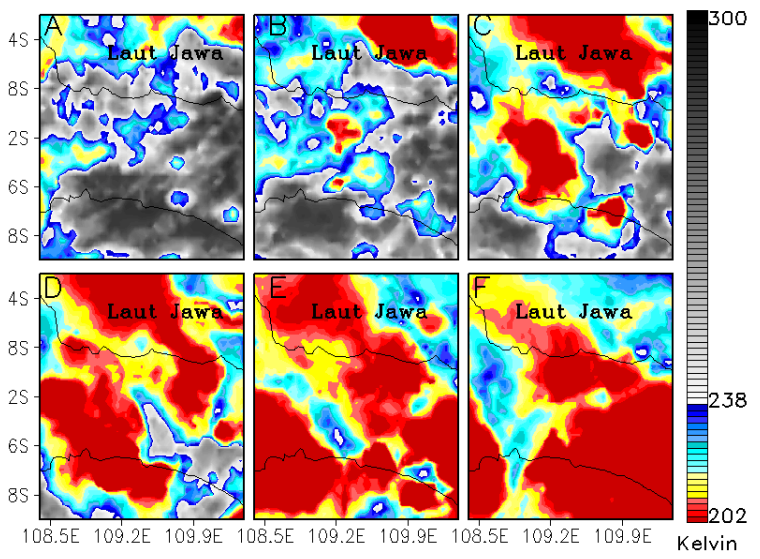

Gambar 11. Sama seperti gambar 3 tapi untuk kasus tanggal 18 Juni 2016. Gambar A, B, C, D, $\mathrm{E}$, dan $\mathrm{F}$ masing-masing adalah untuk pukul 07 , 08, 09, 10, 11, dan 12 UTC.

Di lokasi kejadian awan konvektif terlihat mulai tumbuh secara intensif dimulai pada pukul 16.00 WIB hingga pukul 19.00 WIB (Gambar 12). Sistem awan konvektif ini ditengarai yang menyebabkan terjadinya hujan lebat di lokasi kejadian longsor.
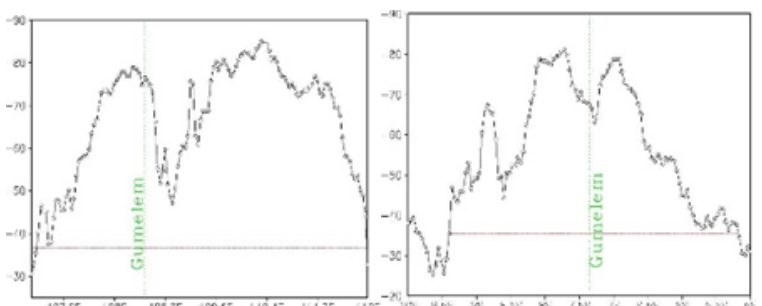

Gambar 12. Irisan zonal (kiri) dan meridional (kanan) dari penampang sistem awan di lokasi kejadian.

Jika dianalisis luasan sistem awan pada saat kejadian mencapai $100.000 \mathrm{~km}^{2}$. Secara luasan sistem ini memenuhi kriteria sebagai meso scale convective complex (MCC). Namun demikian perlu dianalisis lebih lanjut dengan kriteria MCC lainnya.
Gambar 11 menunjukan irisan sistem awan secara zonal dan meridional untuk melihat besarnya sistem awan yang terbentuk saat kejadian hujan lebat. Dapat dilihat bahwa sistem awan pada saat itu memiliki panjang secara horizontal arah zonal sekitar $550 \mathrm{~km}$ dan arah meridional sekitar $500 \mathrm{~km}$.

Pantauan kejadian hujan secara spasial disajikan dengan menggunakan data estimasi hujan berbasis satelit yaitu data GSMAP (Gambar 13). Pada Gambar 13 terlihat bahwa data GSMAP tidak menangkap kejadian hujan lebat di lokasi kejadian longsor pada jam 09.00 UTC seperti yang tercatat di data pengamatan stasiun. Namun demikian pada jam 10 dan 12 UTC hujan dengan intensitas sedang terpantau di wilayah kejadian longsor.

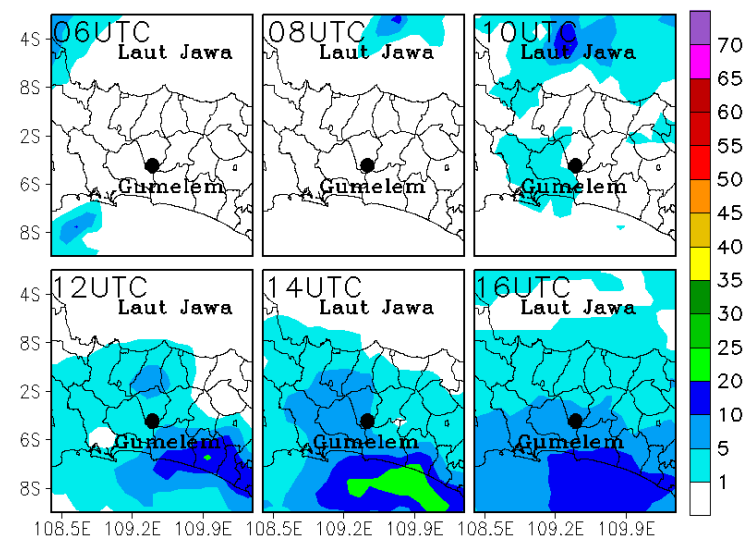

Gambar 13. Distribusi hujan spasial data GSMAP tanggal 18 Juni 2016.

\subsubsection{Keandalan Model WRF dalam Mensimulasikan Kejadian Hujan Lebat Pemicu Longsor}

Hasil simulasi kejadian hujan lebat dengan menggunakan eksperimen Non-DA memperlihatkan bahwa eksperimen tersebut gagal menangkap kejadian hujan lebat yang menyebabkan longsor. Sebaliknya pada eksperimen DA-SAT terlihat kejadian hujan lebat tersimulasikan dengan baik di 
wilayah kejadian longsor (Gambar 14). Hasil ini mengindikasikan bahwa prosedur asimilasi data satelit dapat memperbaiki hasil simulasi.

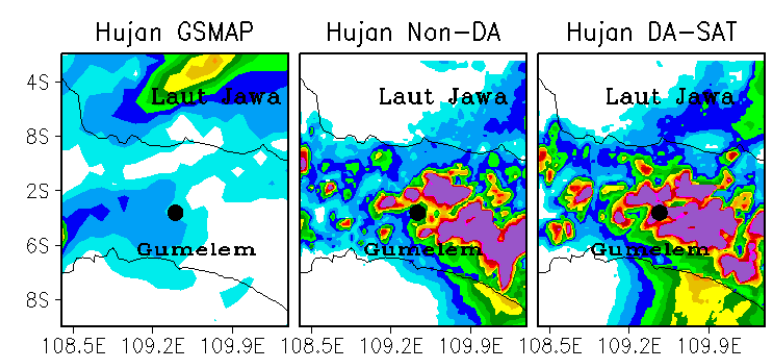

$5 \quad 10152025303540455055606570 \quad \mathbf{m m}$ Gambar 14. Perbandingan distribusi spasial hujan akumulasi 6 jam (7-12 UTC)antara data GSMAP, simulasi hujan eksperimen Non-DA dan eksperimen DA-SAT tanggal 18 Juni 2016.

\section{KESIMPULAN}

Akurasi prediksi hujan lebat di wilayah Indonesia masih sangat rendah (no skill) (Gustari, 2012). Di lain pihak, informasi prediksi hujan lebat sangat dibutuhkan dalam kegiatan mitigasi bencana hidrometeorologi (contoh: kejadian longsor). Usaha perbaikan terus dilakukan untuk meningkatkan kemampuan prediksi kejadian hujan lebat yang menyebabkan bencana hidrometeorologi. Penelitian ini melakukan perbaikan skill prediksi model WRF dengan memperbaiki data asimilasi melalui prosedur asimilasi data satelit cuaca. Hasil analisis menunjukan bahwa prosedur asimilasi data satelit cuaca dapat memperbaiki data awal kandungan uap air $(+60 \%)$ di atmosfer beberapa jam sebelum kejadian hujan lebat. Sehingga hasil prediksi DA_SAT menjadi lebih baik dibandingkan dengan Non_DA. Hal ini ditunjukan dengan nilai kesalahan model yang menjadi lebih kecil (-38\%) jika dibandingkan dengan data pengamatan penakar hujan stasiun. Hasil perbandingan data series waktu akumulasi curah hujan antara DASAT dan Non-DA memperlihatkan adanya perbedaan waktu tercapainya hujan maksimum dan juga perbedaan intensitasnya dimana skema Non-DA lebih lambat (+5 jam) dengan bias (-40\%) sementara DA-SAT lebih lambat 0.5 jam dengan bias $(+8 \%)$. Dapat disimpulkan bahwa asimilasi data satelit dapat memperbaiki kesalahan prediksi jumlah hujan dan waktu kejadiannya.

\section{DAFTAR PUSTAKA}

Baum, R.L., Godt, J.W. (2010). Early Warning of Rainfall-induced Shallow Landslides and Debris Flows in the USA. Landslides, 7(3), 259-272. doi: 10.1007/s10346-009-0177-0

Bonsignori, R. (2007). The Microwave Humidity Sounder (MHS): In-orbit Performance Assessment. Proceedings of SPIE 6744, Sensors, Systems, and Next-Generation
Satellites XI, 67440A (17 October 2007). doi:10.1117/12.737986

Chan, R.K.S., Pang, P.L.R., Pun, W.K. (2003). Recent Developments in the Landslip Warning System in Hong Kong. Proceedings of the Fourteenth Southeast Asian Geotechnical Conference, Southeast Asian Geotechnical Society, 219-224.

Crosta, G., Frattini, P. (2001). Rainfall Thresholds for Triggering Soil Slips and Debris Flow. Proceedings of the EGS 2nd Plinius Conference 2000 on Mediterranean Storms, 463-488.

Glade, T., Crozier, M., Smith, P. (2000). Applying Probability Determination to Refine Landslide-triggering Rainfall Thresholds Using an Empirical "Antecedent Daily Rainfall Model". Pure and Applied Geophysics, 157(6-8), 1059-1079. doi: $10.1007 / \mathrm{s} 000240050017$

Goodrum, G., Kidwell, K., Winston, W. (2009). NOAA KLM user's guide with NOAA-N, N'supplement. NOAA.

Gustari, I., Hadi, T.W., Hadi, S., Renggono, F. (2012). Akurasi Prediksi Curah Hujan Harian Operasional di Jabodetabek: Perbandingan dengan Model WRF. Jurnal Meteorologi dan Geofisika, 13(2), 119-130.

Guzzetti, F., Peruccacci, S., Rossi, M., Stark, C.P. (2008). The Rainfall Intensity-duration Control of Shallow Landslides and Debris Flows: An Update. Landslides, 5(1), 3-17. doi: 10.1007/s10346-007-0112-1

Hamilton, W. (1973). Tectonics of the Indonesian Region. Geological Society of Malaysia, 6, 3-10.

Huggel, C., Khabarov, N., Obersteiner, M., Ramírez, J.M. (2010). Implementation and Integrated Numerical Modeling of a Landslide Early Warning System: A Pilot Study in Colombia. Natural Hazards, 52(2), 501-518. doi: 10.1007/s11069-009-9393-0

Ide, K., Courtier, P., Ghil, M., Lorenc, A.C. (1997). Unified Notation for Data Assimilation: Operational, Sequential and Variational. Journal of the Meteorological Society of Japan, 75(1B), 181-189. doi: 10.2151/jmsj1965.75.1B_181

Iredell, M., Pan, H., Caplan, P. (2002). Changes to the 2002 NCEP Operational MRF/AVN Global Analysis/ Forecast System, National Centers for Environmental Prediction, Global Modeling Branch. Not published.

Kalnay, E., Kanamitsu, M., Kistler, R., Collins, W., Deaven, D., Gandin, L., Iredell, M., Saha, S., White, G., Woollen, J., Zhu, Y., Chelliah, M., Ebisuzaki, W., Higgins, W., Janowiak, J., Mo, K.C., Ropelewski, C., Wang, J., Leetmaa, A., Reynolds, R., Jenne, R., Joseph, D. (1996). The NCEP/NCAR 40year Reanalysis Project. Bulletin of the American Meteorological Society, 77(3), 
437-472, doi: $\quad 10.1175 / 1520$ 0477(1996)077<0437:TNYRP>2.0.CO;2

Kanamitsu, M. (1989). Description of the NMC Global Data Assimilation and Forecast System. Weather and Forecasting, 4(3), 335-342. doi: 10.1175/15200434(1989)004<0335:DOTNGD>2.0.CO;2

Kanamitsu, M., Alpert, J.C., Campana, K.A., Caplan, P.M., Deaven, D.G., Iredell, M., Katz, B., Pan, H.L., Sela, J., White, G.H. (1991). Recent Changes Implemented into the Global Forecast System at NMC. Weather and Forecasting, 6(3), 425-435. doi: $10.1175 / 1520$ 0434(1991)006<0425:RCIITG>2.0.CO;2

Keefer, D.K., Wilson, R.C., Mark, R.K., Brabb, E.E., Brown III, W.M., Ellen, S.D., Harp, E.L., Wieczorek, G.F., Alger, C.S., Zatkin, R.S. (1987). Real-Time Landslide Warning During Heavy Rainfall. Science, 238, Issue 4829, 921-925. doi: 10.1126/science.238.4829.921

Kubota, T., Okamoto, K., Shige, S., Ushio, T., Iguchi, T., Takahashi, N., Iwanami, K., Aonashi, K., Kachi, M., Oki, R. (2007). The Global Satellite Mapping of Precipitation
(GSMaP) Project. The 7th GPM International Planning Workshop Bellesale Kudan, Tokyo, Japan.

Martelloni, G., Segoni, S., Fanti, R., Catani, F. (2012). Rainfall Thresholds for the Forecasting of Landslide Occurrence at Regional Scale. Landslides, 9(4), 485-495. doi: 10.1007/s10346-011-0308-2

Mubekti., Alhasanah, F. (2008). Mitigasi Daerah Rawan Tanah Longsor Menggunakan Teknik Pemodelan Sistem Informasi Geografis (Studi Kasus: Kecamatan Sumedang Utara dan Sumedang Selatan). Jurnal Teknik Lingkungan, 9(2),121-129.

Rosi, A., Peternel, T., Jemec-Auflic, M., Komac, M., Segoni, S., Casagli, N. (2016). Rainfall Thresholds for Rainfall-induced Landslides in Slovenia. Landslides, 13(6), 1571-1577. doi: 10.1007/s10346-016-0733-3

Skamarock, W.C., Klemp, J.B., Dudhia, J., Gill, D.O., Barker, D.M., Wang, W., Powers, J.G. (2008). A Description of the Advanced Research WRF Version 3. NCAR Technical Note NCAR/TN-475+STR. doi:10.5065/D68S4 MVH. 